\title{
Investigation of the Initial Host Response of Naïve Atlantic Salmon (Salmo salar) Inoculated with Paramoeba perurans
}

\author{
Michelle McCormack ${ }^{1}{ }^{*}$, Eugene Dillon ${ }^{2}$, Ian $\mathrm{O}^{\prime}$ Connor $^{1}$ and Eugene MacCarthy ${ }^{1}$ \\ 1 Marine and Freshwater Research Centre, Galway Mayo Institute of Technology, Dublin Road, \\ H91 TRNW Galway, Ireland; Ian.OConnor@gmit.ie (I.O.); Eugene.McCarthy@gmit.ie (E.M.) \\ 2 Conway Institute of Biomolecular \& Biomedical Research, University College Dublin, \\ D04 V1W8 Dublin, Ireland; eugene.dillon@ucd.ie \\ * Correspondence: michelle.mccormack@gmit.ie
}

check for updates

Citation: McCormack, M.; Dillon, E.; O'Connor, I.; MacCarthy, E. Investigation of the Initial Host Response of Naïve Atlantic Salmon (Salmo salar) Inoculated with Paramoeba perurans. Microorganisms 2021, 9, 746. https://doi.org/ 10.3390/microorganisms 9040746

Academic Editors: James W. Wynne and Barbara Nowak

Received: 5 February 2021

Accepted: 31 March 2021

Published: 2 April 2021

Publisher's Note: MDPI stays neutral with regard to jurisdictional claims in published maps and institutional affiliations.

Copyright: (c) 2021 by the authors. Licensee MDPI, Basel, Switzerland. This article is an open access article distributed under the terms and conditions of the Creative Commons Attribution (CC BY) license (https:/ / creativecommons.org/licenses/by/ $4.0 /)$.

\begin{abstract}
Amoebic Gill Disease (AGD), caused by the ectoparasite Paramoeba perurans is characterised by hyperplasia of the gill epithelium and lamellar fusion. In this study, the initial host response of naïve Atlantic salmon (Salmo salar) inoculated with P. perurans was investigated. Using gel-free proteomic techniques and mass spectrometry gill and serum samples were analysed at 7 timepoints $(2,3,4,7,9,11$ and 14 days) post-inoculation with $P$. perurans. Differential expression of immune related proteins was assessed by comparison of protein expression from each time point against naïve controls. Few host immune molecules associated with innate immunity showed increased expression in response to gill colonisation by amoebae. Furthermore, many proteins with roles in immune signalling, phagocytosis and T-cell proliferation were found to be inhibited upon disease progression. Initially, various immune factors demonstrated the anticipated increase in expression in response to infection in the serum while some immune inhibition became apparent at the later stages of disease progression. Taken together, the pro-immune trend observed in serum, the lack of a robust early immune response in the gill and the diversity of those proteins in the gill whose altered expression negatively impact the immune response, support the concept of a pathogen-derived suppression of the host response.
\end{abstract}

Keywords: amoebic gill disease; Atlantic salmon; gel-free proteomics; gill proteome; serum proteome

\section{Introduction}

Amoebic Gill Disease (AGD), first described in Tasmania in 1986 [1], is caused by the marine ectoparasite Paramoeba perurans, and as the number of cases reported worldwide has escalated in recent years, it has become recognised as one of the most significant health threats in salmon farming [2]. Diseased fish exhibit multifocal gill hyperplasia, lamellar fusion, increased mucus production and macroscopic lesions on gill filaments [3]. The resultant respiratory distress can lead to mortality in up to $80 \%$ of cases if left untreated [4]. Treatments are limited to fresh water or hydrogen peroxide baths, which effectively remove the amoebae from affected gills and reduce gill mucus viscosity [5,6], however neither treatment prevents re-infection [7]. The economic impact of AGD is not insignificant, with an estimated $20 \%$ additional production costs being placed on farmers as a direct consequence of fish loss and treatment [8].

Several studies have focused on gill gene expression analyses in order to investigate host response in AGD. Some have highlighted a transcriptional down-regulation of key immune factors, such as interferon induced MHC I and MHC II pathways and anti-oxidant enzymes $[9,10]$, while others have noted up-regulation of pro-inflammatory cytokine and immune-regulatory gene transcription $[11,12]$ as a typical response to AGD. Some of the most significant genomic responses to the disease were found to be lesion specific [12,13], which, when compared with data obtained from non-lesion areas, appear contradictory. This has led to the contention that genetic screening focusing on lesion tissue, without 
adequately accounting for infiltration of immune factors from surrounding cells, could give rise to results, which may, if interpreted in the context of the entire gill, misrepresent the cellular response to the parasitic infection [14]. However, it has also been demonstrated that the cellular composition and ratio of cell types within the gill are subject to variation dependent on disease status, developmental stage and experimental conditions, and these may also account for some of the variations observed between studies [15].

Other studies have reported on serum immune parameters in AGD infected salmon, though many of the traditional factors such as immunoglobulins and immune related enzymes remained unaltered or yielded varying results in the disease condition [16-18]. Although the work done to date has made progress towards understanding AGD, differences in disease stage, amoebic load, exposure duration and environmental conditions make comparisons between studies difficult and further work is required to fully elucidate the host response in AGD from early to late disease stage, at both a local and systemic level.

In aquaculture, proteomics has gained recognition as a technique which can yield valuable information regarding a biological system and provide greater understanding of the pathophysiology of disease, than genomics alone [19]. Previously, proteomic analysis of salmon gill and skin mucus implicated several inflammatory pathways and immune molecules in the host response to repeated P. perurans infection [20]. Marcos-Lopez et al. [18] were the first to use gel-based proteomics to investigate disease progression in salmon gills across 6 sequential timepoints in AGD affected fish and highlighted proteins involved in cell proliferation, immunity, oxidative metabolism and cytoskeletal reorganisation as being among those most significantly altered in the disease state.

Limitations of the traditional 2DPAGE proteomics, particularly with respect to gel to gel variation and limited proteome coverage $[19,21]$, have led to the rise in popularity of gel free proteomic techniques [22,23]. Therefore, in this study whole gill arches and blood samples from salmon with AGD, from 7 time points spanning sub-clinical and clinical stages of the disease, were submitted to a filter-based sample preparation and in-solution tryptic digestion followed by label-free mass spectrometry analysis [22,24]. Analysis of differential gill and serum protein expression across all time points, in comparison to control fish will contribute to the understanding of the pathophysiology of this disease, and the salmon host response to the infection at both a local and systemic level.

\section{Materials and Methods}

\subsection{Fish Husbandry}

Atlantic salmon reared on a land-based freshwater hatchery in the west of Ireland, were transferred to a land-based indoor, marine recirculating facility at the Marine and Freshwater Research Centre (MFRC) at the Galway-Mayo Institute of Technology (GMIT) in Galway, Ireland following smoltification. Salmon smolts (average weight $70 \mathrm{~g}$ ) were distributed into four circular black $1000 \mathrm{~L}$ tanks $(n=45 / \operatorname{tank})$ with the following conditions: stocking density $3.6 \mathrm{~kg} \mathrm{~m}^{-3}$, water temperature $12{ }^{\circ} \mathrm{C}$, artificial salinity of 30 parts per thousand (ppt) (Coral Pro salt, Red Sea), light cycle of $12 \mathrm{~h}$ light, $12 \mathrm{~h}$ dark. Fish were fed a commercial salmon diet at $1 \%$ body weight per day. This project was authorised by the Health Products Regulatory Authority (HPRA) in Ireland under project authorisation number AE19137/P001, in compliance with the requirements under Directive 2010/63/EU transposed into Irish law by the European Union (Protection of Animals Used for Scientific Purposes) Regulations 2012 (S.I. No 543 of 2012 as amended).

\subsection{Paramoeba perurans Challenge and Sample Collection}

Following an acclimatisation period of 6 days, 90 fish $(45 \times 2)$ were challenged with P. perurans (2750 amoebae/L) in a volume of $300 \mathrm{~L}$ for $4 \mathrm{~h}$ with oxygen saturation. This challenge load was similar to that employed in other studies which successfully induced AGD [12,25]. Fish behaviour and welfare were closely monitored. Control fish, also 90 fish $(45 \times 2)$, were also held in $300 \mathrm{~L}$ for $4 \mathrm{~h}$. Following the challenge period, the control and treatment fish were moved into new tanks containing $1000 \mathrm{~L}$ seawater. To confirm the 
identity of the amoebae, real-time polymerase chain reaction (PCR) was carried out, as described by Downes [26], at the National Reference Laboratory for finfish disease, Marine Institute, Galway, Ireland.

Gill and blood samples were collected from four control salmon pre-challenge ( 0 days post infection (dpi)) and then a further four at each of the following timepoints post P. perurans challenge: 2 dpi, 3 dpi, 4 dpi, 7 dpi, 9 dpi, 11 dpi and 14 dpi. Fish were euthanised by overdose of anaesthetic ( $400 \mathrm{mg} / \mathrm{L}$ tricaine methanesulfonate (MS-222)) and gills scored in accordance with the standard commercial protocol, adapted from Taylor et al. [3]. For histological analyses, the first gill arch on the left side of each fish was excised and immediately fixed in $10 \%$ neutral buffered formalin. For gill proteomic analysis, the 2nd right gill arch from each fish was excised, the arch cartilage removed, and the remaining gill filaments snap frozen in dry ice and kept at $-80^{\circ} \mathrm{C}$ until required. For serum proteomic analysis, blood was obtained from the caudal vein of each specimen and incubated at $4{ }^{\circ} \mathrm{C}$ overnight. Blood samples were spun at $10,000 \times g$ for 5 min at $4{ }^{\circ} \mathrm{C}$ and the serum was retained and stored at $-80^{\circ} \mathrm{C}$ until required.

\subsection{Histology}

Fixed gill samples were routinely processed and embedded in paraffin wax blocks. Sections $(5 \mu \mathrm{m})$ were stained with haematoxylin and eosin (H\&E) and examined using an Olympus BX41 Microscope and CellSens software (Olympus, Tokyo, Japan). Gill filaments exhibiting features of AGD including lamellar fusion, hyperplasia and vesicle formation were imaged.

\subsection{Proteomics FASP}

Gills were weighed, and tissue lysis was performed, on ice, by sonication $(4 \times 30 \mathrm{~s}$ cycles at 25\% amplitude; Fisherbrand ${ }^{\mathrm{TM}}$ Q500 Sonicator, Waltham, MA, USA), in a $50 \mathrm{mM}$ Tris, $1 \%$ SDS lysis buffer. Protein quantification was carried out using the Pierce BCA assay (Thermo Scientific) and $300 \mu \mathrm{g}$ of protein were incubated with $0.1 \mathrm{M} \mathrm{DTT}$ at $95{ }^{\circ} \mathrm{C}$ for $10 \mathrm{~min}$. Serum samples were thawed, and protein quantification was carried out using the Pierce BCA assay. In total, $300 \mu \mathrm{g}$ of protein were diluted 1 in 10 in a $50 \mathrm{mM}$ Tris, $1 \%$ SDS lysis buffer and incubated with $0.1 \mathrm{M}$ DTT at $95^{\circ} \mathrm{C}$ for $10 \mathrm{~min}$. For both gill and serum samples, clean up and digestion steps were carried out using the FASP method based on that described by Wiśniewski et al. [24]. Briefly, samples were mixed with UA buffer ( $8 \mathrm{M}$ urea, $100 \mathrm{mM}$ Tris- $\mathrm{HCl} \mathrm{pH} \mathrm{8.9)}$ and contaminants and salts were removed by repeated ultrafiltration through $10 \mathrm{kDa}$ Vivacon centrifugal concentrators (Sartorius, Göttingen, Germany). Samples were incubated for $20 \mathrm{~min}$ in darkness with $100 \mu \mathrm{L} 50 \mathrm{mM}$ iodoacetamide in UA buffer, to facilitate blocking of reduced cysteine residues. After further washes with UA and $50 \mathrm{mM}$ ammonium bicarbonate (ABC), trypsin (1 $\mathrm{gg}$ per $100 \mu \mathrm{g}$ protein; Sigma-Aldrich, St. Louis, MO, USA) in $40 \mu \mathrm{L}$ ABC was added to the samples in the concentrator units. Digestion was performed at $37^{\circ} \mathrm{C}$ for $4 \mathrm{~h}$. The resulting peptide fragments were washed with $\mathrm{ABC}$ and digestion was halted by the addition of $5 \mu \mathrm{L} \mathrm{50 \%}$ acetic acid. The eluates were desalted on C18 - Stage tips (Sigma-Aldrich) [27], dried in a vacuum concentrator (Eppendorf Vacufuge concentrator 5301) and stored at $-20{ }^{\circ} \mathrm{C}$ until mass spectrometry analysis.

\subsection{Mass Spectrometry}

The samples were analysed by the Mass Spectrometry Resource (MSR) in University College, Dublin on a Thermo Scientific Q Exactive mass spectrometer connected to a Dionex Ultimate 3000 (RSLCnano, Waltham, MA, USA) chromatography system. Peptides were separated on C18 home-made column (C18RP Reprosil-Pur, Ammerbuch, Germany, $100 \times 0.075 \mathrm{~mm} \times 3 \mu \mathrm{m}$ ) over $60 \mathrm{~min}$ at a flow rate of $250 \mathrm{~nL} / \mathrm{min}$ with a linear gradient of increasing acetonitrile (ACN) from $1 \%$ to $27 \%$. The mass spectrometer was operated in data-dependent mode; a high resolution $(70,000)$ MS scan $(300-1600 \mathrm{~m} / z)$ was performed to 
select the twelve most intense ions and fragmented using high energy C-trap dissociation for MS/MS analysis.

\subsection{Data Processing and Bioinformatics}

Raw data from the Q-Exactive were processed using the MaxQuant $[28,29]$ (version 1.6.4.0) incorporating the Andromeda search engine [30]. To identify peptides and proteins, MS /MS spectra were matched against the Uniprot Salmo salar database (2019_04) containing 82,390 entries. All searches were performed using the default setting of MaxQuant, with trypsin as specified enzyme allowing two missed cleavages and a false discovery rate of $1 \%$ on the peptide and protein level. The database searches were performed with carbamidomethyl $(\mathrm{C})$ as fixed modification and acetylation (protein $\mathrm{N}$ terminus) and oxidation (M) as variable modifications. For the generation of label free quantitative (LFQ) ion intensities for protein profiles, signals of corresponding peptides in different nanoHPLC MS/MS runs were matched by MaxQuant in a maximum time window of $1 \mathrm{~min}$ [31]. The mass spectrometry proteomics data have been deposited to the ProteomeXchange Consortium via the PRIDE [32] partner repository with the dataset identifier PXD022101.

\subsection{Data Analysis}

Data were processed using the Perseus (v 1.6.7.0) data analysis suite (https: / / maxquant. net/perseus / (accessed on 9 January 2020)). Label free quantitative (LFQ) ion current intensities were transformed $\left(\log _{2}\right)$. Imputation was carried out to replace missing values with numbers drawn from a normal distribution. A Student's $t$-test was performed to determine statistical significance $(p<0.05)$. For visualisation using heatmaps, data were $\mathrm{z}$-score normalised. Fold change values were obtained by calculating the difference between the two compared conditions of the mean $\log _{2}$ transformed values, and the Student's $t$-test $p$-value. Pathway enrichment analysis was performed using the ClueGo (v 2.5.4) [33] and Cluepedia (v 1.5.7) [34] plugins in Cytoscape (v 3.7.1) [35] with the salmo salar (8030) marker set. The gene ontology immune system process, consisting of 466 genes, was used [36,37]. GO tree levels $(\min =3 ; \max =8)$ and GO term restriction (min\#genes $=3, \min \%=4 \%$ ) were set and terms were grouped using a Kappa Score Threshold of 0.4. The classification was performed by the two-side hypergeometric statistic test, and the probability value was corrected by the Bonferroni method (adjusted \% term $p$-value $<0.05$ ) [33].

\section{Results}

\subsection{In Vivo Challenge, RT-PCR and Histopathology}

The identity of the amoebae was confirmed by real-time polymerase chain reaction (PCR) as described by Downes et al. [26]. By 2 dpi, 5 of 6 fish tested positive for the presence of $P$. perurans. At $7 \mathrm{dpi}$, all 6 fish tested were positive for P. perurans. The first lesions were observed at $11 \mathrm{dpi}$. Gill scoring was undertaken in accordance with the standard commercial protocol adapted from Taylor et al. [3], and, in compliance with regulations, the trial was halted when a gill score of 2 was achieved by $50 \%$ of fish. Histopathological analysis revealed hyperplastic lesions, interlamellar vesicles and hyperplastic lamellar fusion at $14 \mathrm{dpi}$ (Figure 1).

\subsection{Gill Proteomics}

In excess of 5000 proteins were initially identified by mass spectrometry. Upon filtering based on matching more than one peptide in each case and performing Student's $t$-test statistics on normalised and imputed data, 180 proteins were found to be differentially expressed at $2 \mathrm{dpi}, 178$ proteins at $3 \mathrm{dpi}, 136$ proteins at $4 \mathrm{dpi}, 239$ proteins at $7 \mathrm{dpi}$, 212 proteins at $9 \mathrm{dpi}, 335$ proteins at $11 \mathrm{dpi}$ and 667 proteins at $14 \mathrm{dpi}(p<0.05)$. The number of proteins differentially expressed was highest at $14 \mathrm{dpi}$, which is in line with the progression of classic disease features, as confirmed by gill scoring and histopathology analyses. Between $13 \%$ and $29 \%$ of these proteins exhibited a $t$-test difference of at least $+/-1.5$, across the 7 time points, a total of 393 proteins (Figure 2). In the gill, less than $10 \%$ 
of differentially expressed proteins were components of the host immune system. $t$-test difference values across all timepoints for proteins involved in immunity are displayed in Table 1. The differential expression of those gill proteins which have a role in complement stimulation and complement inhibition, across all time points, relative to control values, are displayed in Figures 3A and 4A, respectively. Immune system process pathway analysis of gill samples, carried out using the Cluego app (v 2.5.7) in Cytoscape (v 1.5.7), identified no immune pathway enrichment at any timepoint in gill samples.
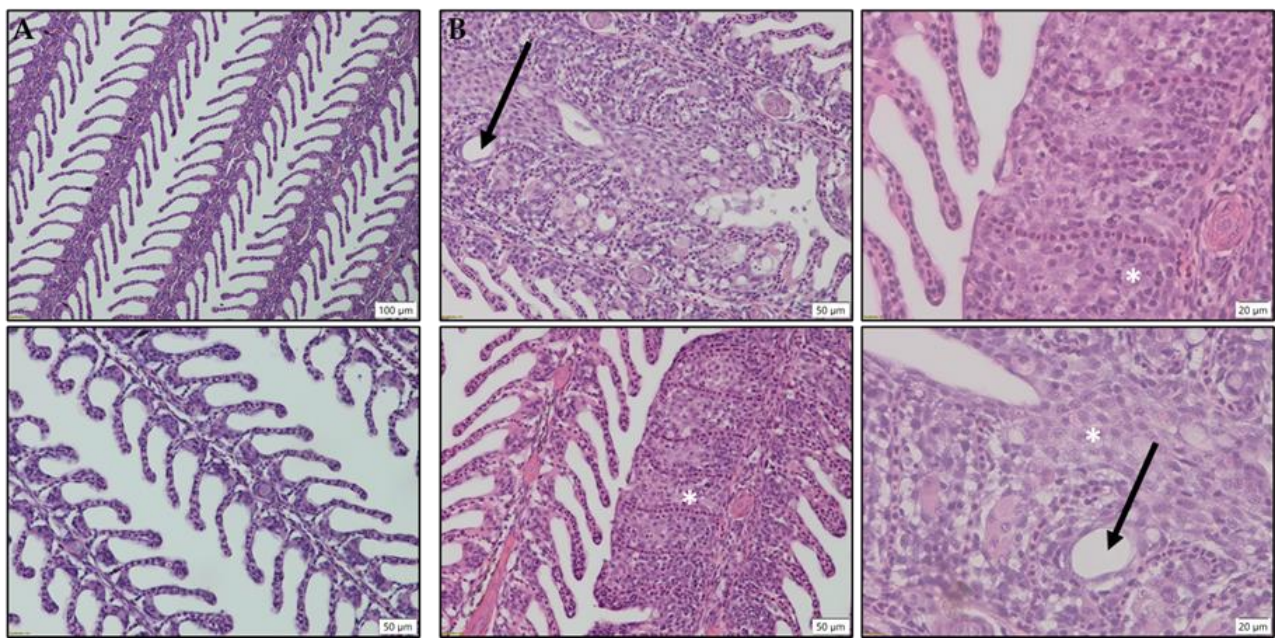

Figure 1. Histology (H\&E staining) of salmon gill samples: (A) Gill samples from pre-inoculation controls and (B) gills from salmon sampled $14 \mathrm{dpi}$. Features commonly associated with AGD including Hyperplastic lesions, hyperplastic lamellar fusion $\left(^{*}\right)$ and interlamellar vesicles (black arrows) and were evident in gill samples at $14 \mathrm{dpi}$. Scale bars are indicated on images.

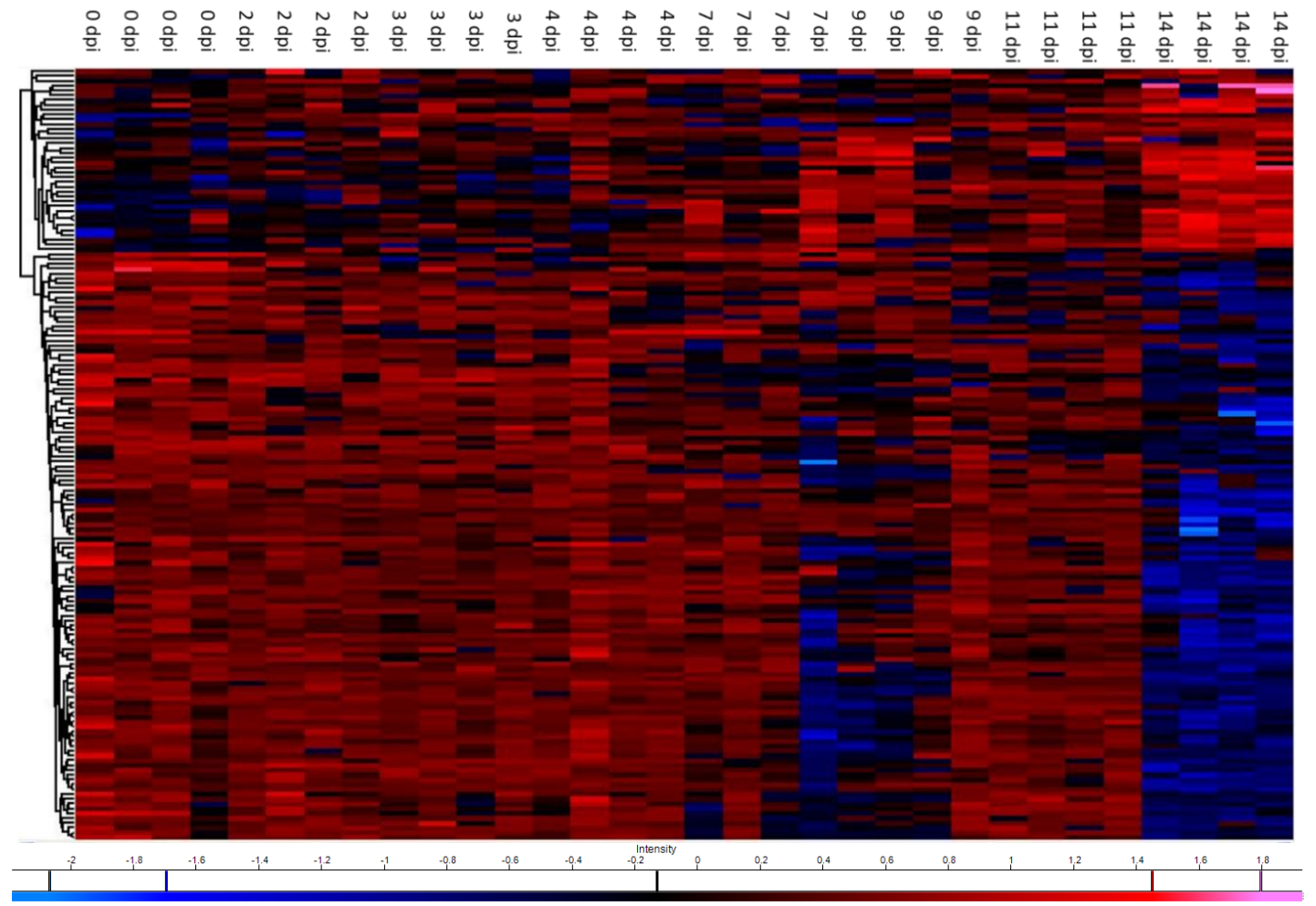

Figure 2. Heatmap plot of the proteins exhibiting $t$-test differences of at least $+/-1.5$ in control and post infection samples after LFQ values were z-score normalised. Hierarchical clustering was performed using Euclidian distance and average linkage using the Perseus software. 


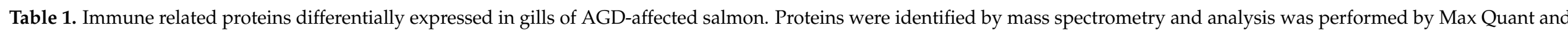

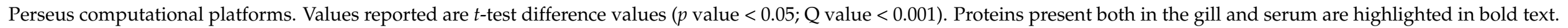

\begin{tabular}{|c|c|c|c|c|c|c|c|c|c|c|}
\hline Name & Gene & 2 dpi & $3 \mathrm{dpi}$ & 4 dpi & $7 \mathrm{dpi}$ & $9 \mathrm{dpi}$ & $11 \mathrm{dpi}$ & $14 \mathrm{dpi}$ & Peptide Matches & $\%$ Sequence Coverage \\
\hline $\begin{array}{l}\text { 1-phosphatidylinositol 4,5-bisphosphate } \\
\text { phosphodiesterase delta-1 }\end{array}$ & A0A1S3QBL3 & & & & -1.76 & -1.61 & & -1.35 & 6 & 22.00 \\
\hline $\begin{array}{l}\text { Aminoacyl tRNA synthase complex-interacting } \\
\text { multifunctional protein 2-like }\end{array}$ & A0A1S3S257 & & & & -1.82 & & & & 2 & 26.6 \\
\hline Apolipoprotein A-I isoform X1 & A0A1S3NQ06 & & & -0.91 & & & & & 33 & 78.2 \\
\hline Apolipoprotein A-I precursor & В5ХВН3 & & & -1.33 & & & & & 31 & 78.6 \\
\hline Apolipoprotein A-I-like & A0A1S3N6U9 & & & & 2.08 & & & 2.72 & 7 & 34.50 \\
\hline Apolipoprotein A-IV & B5X8U6 & & & & 1.45 & 1.30 & & & 6 & 29.00 \\
\hline Apolipoprotein C-I isoform X1 & A0A1S3RYY8 & & & & & & -0.62 & & 8 & 55.2 \\
\hline Apolipoprotein C-I-like & A0A1S3N6L4 & & & & & & -1.51 & & 8 & 60.90 \\
\hline Apolipoprotein Eb-like & A0A1S3RXT3 & & & & & & -2.40 & & 17 & 59.80 \\
\hline Apolipoprotein Eb-like & A0A1S3N6Y0 & & & & & & -0.83 & & 18 & 69.1 \\
\hline Calcium uniporter protein, mitochondrial & A0A1S3QKG0 & & & & & & 1.82 & & 3 & 11.50 \\
\hline Calpain-2 catalytic subunit-like & A0A1S3Q7N2 & & & & & & & -2.05 & 22 & 43.80 \\
\hline Cation-dependent mannose-6-phosphate receptor & B5X109 & & & 2.01 & & & & & 3 & 10.40 \\
\hline Complement C4-like(LOC106605920) & A0A1S3RYT8 & & & & -1.68 & & 1.75 & 1.75 & 22 & 18.20 \\
\hline Complement component $\mathrm{C} 6$ precursor & COH9G0 & & 0.45 & 1.16 & & 0.63 & 0.59 & 0.71 & 6 & 7.8 \\
\hline Complement factor $\mathrm{H}$-like & A0A1S3QR20 & & & & & & & 1.28 & 37 & 50.1 \\
\hline Complement factor $\mathrm{H}$-like & A0A1S3KK78 & & & & & & & 0.93 & 12 & 36.9 \\
\hline Complement factor I(cfi) & A0A1S3QGX2 & 1.92 & 1.89 & 1.68 & & 1.94 & 1.92 & 1.37 & 6 & 13.10 \\
\hline $\begin{array}{l}\text { Deoxynucleoside triphosphate triphosphohydrolase } \\
\text { SAMHD1-like(LOC106593439) }\end{array}$ & A0A1S3QJS3 & -0.62 & & -1.59 & & & -1.39 & & 5 & 37.80 \\
\hline Dicarbonyl and L-xylulose reductase(dcxr) & B5X5V8 & & & & -2.10 & -2.22 & -2.96 & & 3 & 13.10 \\
\hline DnaJ homolog subfamily A member 2 & COHBK7 & & & & 6.13 & 4.73 & & & 11 & 24.80 \\
\hline DnaJ homolog subfamily C member 3-like & A0A1S3SDE5 & -1.96 & & & & & & & 8 & 15.30 \\
\hline
\end{tabular}


Table 1. Cont

\begin{tabular}{|c|c|c|c|c|c|c|c|c|c|c|}
\hline Name & Gene & $2 \mathrm{dpi}$ & 3 dpi & 4 dpi & 7 dpi & 9 dpi & $11 \mathrm{dpi}$ & $14 \mathrm{dpi}$ & Peptide Matches & $\%$ Sequence Coverage \\
\hline Eosinophil peroxidase-like(LOC106572735) & A0A1S3MI56 & & & -2.11 & -1.74 & -1.47 & -1.15 & -2.05 & 34 & 50.50 \\
\hline Granulins-like isoform X2 & A0A1S3NEN1 & & -2.12 & -2.40 & & & -2.09 & -1.77 & 2 & 3.10 \\
\hline Heterogeneous nuclear ribonucleoprotein A0 & B5X0T7 & & & & & & -2.12 & -1.52 & 9 & 28.70 \\
\hline Histone H2A & B5X851 & & & & & & & -1.80 & 7 & 41.40 \\
\hline Inositol-1-monophosphatase & N0GT48 & & & & & & & -1.66 & 3 & 14.60 \\
\hline Intestinal mucin-like protein(LOC106595068) & 106595068 & & & & 1.05 & & 0.78 & 1.29 & 26 & 39.10 \\
\hline Leucine-rich repeat-containing protein 59-like & A0A1S3Q6W9 & & & & & & -2.09 & & 4 & 13.30 \\
\hline Leukocyte elastase inhibitor & B5X4J0 & & -1.06 & -1.06 & -1.59 & & -1.62 & & 8 & 28.50 \\
\hline Magnesium transporter protein 1-like & A0A1S3QGC3 & & & & -2.23 & -2.42 & & & 5 & 17.10 \\
\hline Mucin-2-like & A0A1S3QHF9 & & & & 0.93 & & & 1.10 & 19 & 22.30 \\
\hline Mucin-5AC-like & A0A1S3R574 & & & & 0.63 & & & & 17 & 54.80 \\
\hline Mucin-5B-like & A0A1S3QG78 & & & & & & 0.81 & & 36 & 49.60 \\
\hline Myosin, light polypeptide 3-3 & B5DGT3 & & & & & & & -2.45 & 5 & 34.80 \\
\hline Nuclear Receptor Coactivator 5 & B5X1C7 & & & & & -2.71 & & & 10 & 16.00 \\
\hline Pollen-specific leucine-rich repeat extensin-like protein 1 & A0A1S3QST0 & & & & 1.73 & & & & 4 & 23.40 \\
\hline Polypyrimidine tract-binding protein 2 & B5X232 & & & & & & & 1.54 & 13 & 34.20 \\
\hline Polypyrimidine tract-binding protein 3-like & A0A1S3QGP4 & & & & & & -1.58 & 1.02 & 8 & 23.30 \\
\hline Ras-related protein Rab-11A(rb11a) & B5X4W2 & & & & -3.09 & -3.01 & -3.51 & -2.73 & 9 & 39.40 \\
\hline $\begin{array}{l}\text { Sodium/potassium-transporting ATPase subunit } \\
\text { alpha-1-like(LOC106610479) }\end{array}$ & A0A1S3SLV8 & & -1.26 & -0.96 & -2.63 & -2.81 & -3.32 & & 39 & 38.60 \\
\hline Trafficking protein particle complex subunit & COH7U8 & & & & -1.76 & & & & 4 & 24.40 \\
\hline Transgelin & B9ENC8 & & & & & & & -1.52 & 19 & 77.70 \\
\hline Zymogen granule membrane protein 16-like & A0A1S3KWW8 & & & & 0.81 & 0.94 & & 1.84 & 5 & 38.50 \\
\hline
\end{tabular}



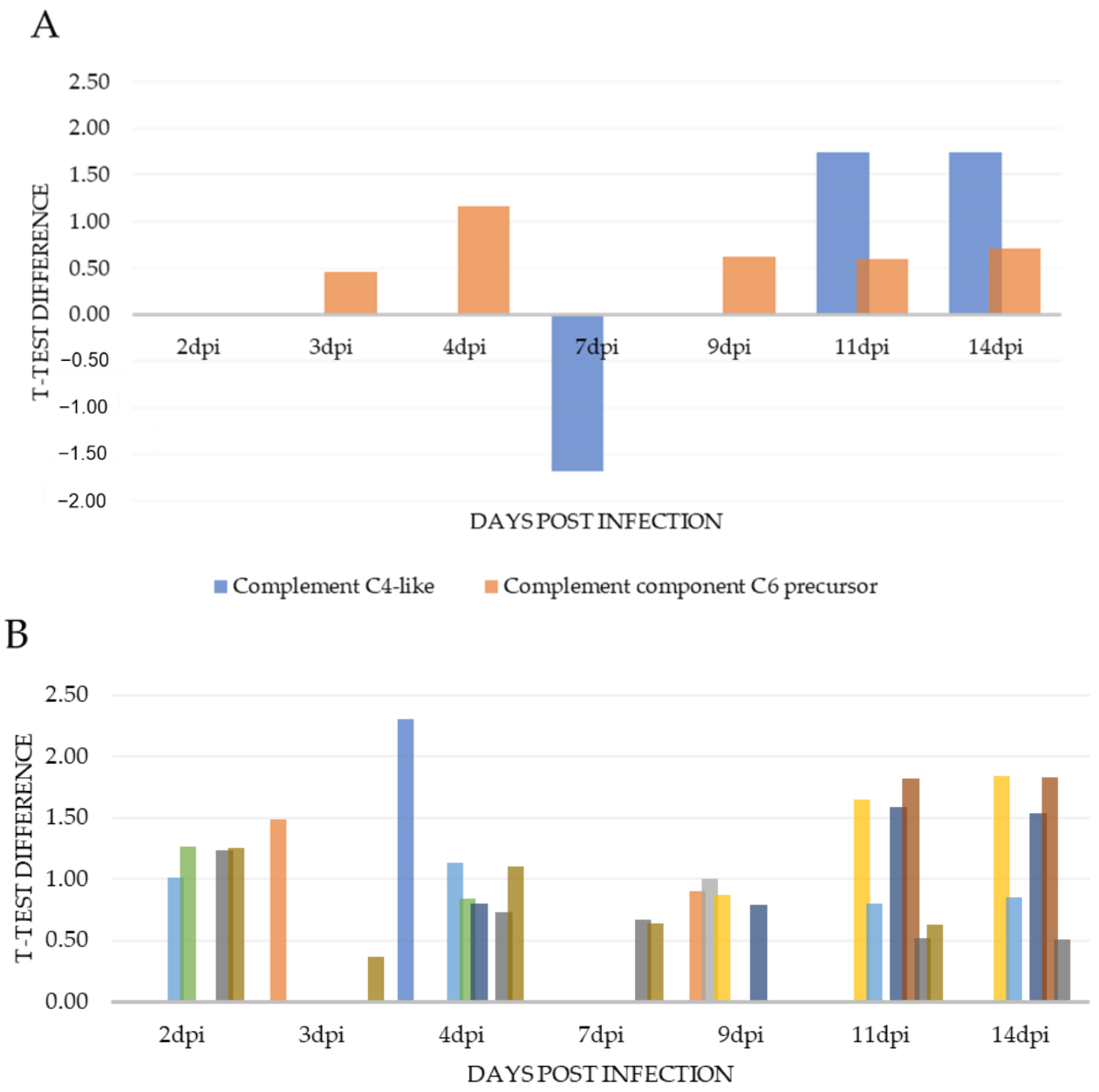

$\begin{array}{ll}\square \text { Complement C1q subcomponent subunit C } & \text { Complement C1r-A subcomponent-like } \\ \square \text { Complement C3-like } & \text { Complement C4-B } \\ \square \text { Complement C4-B-like } & \text { Complement C4-like } \\ \square \text { Complement C4-like } & \square \text { Complement C4-like } \\ \square \text { Complement component C9 } & \square \text { Complement factor B-like }\end{array}$

Figure 3. Pro-immune complement factors: $t$-test difference values for pro-immune complement factors in gill (A) and serum (B) samples across 7 timepoints relative to control values. 
A

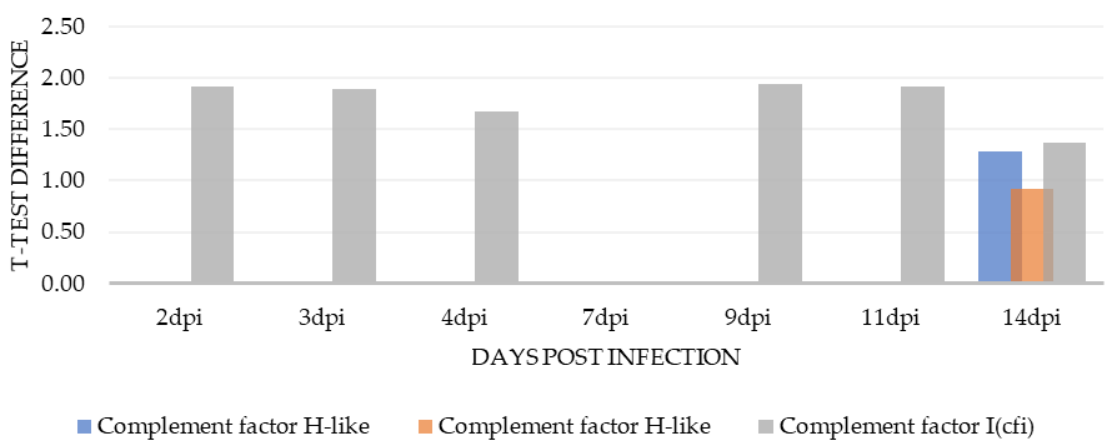

B

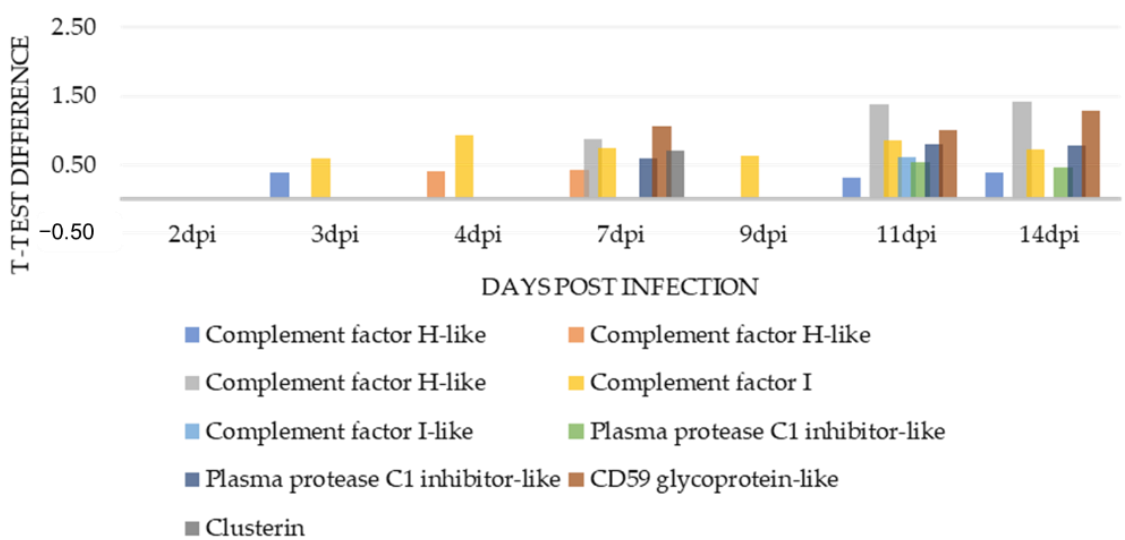

Figure 4. Immuno-inhibitory complement factors: $t$-test difference values for complement inhibitory factors in gill (A) and serum (B) samples across 7 timepoints relative to control values.

\subsection{Serum Proteomics}

In excess of 600 proteins were initially identified by mass spectrometry. Upon filtering based on matching more than one peptide in each case and performing Students' $t$-test statistics on normalised and imputed data, 28 proteins were found to be differentially expressed at $2 \mathrm{dpi}, 25$ proteins at $3 \mathrm{dpi}, 41$ proteins at $4 \mathrm{dpi}, 31$ proteins at $7 \mathrm{dpi}, 40$ proteins at $9 \mathrm{dpi}, 70$ proteins at $11 \mathrm{dpi}$ and 81 proteins at $14 \mathrm{dpi}(p<0.05)$. As in the gill, the number of proteins differentially expressed was highest at $14 \mathrm{dpi}$. Between $24 \%$ and $75 \%$ of these proteins exhibited a $t$-test difference of at least $+/-1.2$, across the 7 time points, a total of 119 proteins. Approximately $47 \%$ of differentially expressed serum proteins had immune related functions. Of these, $64 \%$ were involved in the complement cascade, or were members of the apolipoprotein family. $t$-test difference values across all timepoints for those proteins involved in immunity are detailed in Table 2 . The differential expression of those serum proteins which have a role in complement stimulation and complement inhibition, across all time points, relative to control values, are displayed in Figures $3 \mathrm{~B}$ and $4 \mathrm{~B}$, respectively. Immune system process pathway analysis of serum samples was carried out using the Cluego app ( $\mathrm{v}$ 2.5.7) in Cytoscape ( $\mathrm{v}$ 1.5.7). Up-regulation of pro-immune pathways was evident at 3, 4 and 7 dpi (Supplemental Figure S1A-C). Immune enrichment was absent at $9 \mathrm{dpi}$, but was restored by $11 \mathrm{dpi}$ (Supplemental Figure S1D). At $11 \mathrm{dpi}$ and $14 \mathrm{dpi}$, the pro-immune pathway up-regulation was accompanied by an elevation of various pathways which negatively regulate immunity (Supplemental Figure S1D,E). 


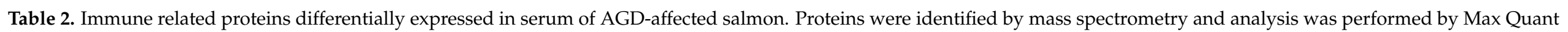
and Perseus computational platforms. Values reported are $\pm t$-test differences ( $p$ value $<0.05$; $Q$ value $<0.001$ ). Proteins present in both gill and serum are highlighted in bold text.

\begin{tabular}{|c|c|c|c|c|c|c|c|c|c|c|}
\hline Name & Gene & 2 dpi & 3 dpi & 4 dpi & 7 dpi & 9 dpi & $11 \mathrm{dpi}$ & $14 \mathrm{dpi}$ & Peptide Matches & $\%$ Sequence Coverage \\
\hline Apolipoprotein A-I isoform X1 & A0A1S3NQ06 & & & & & & -0.32 & -0.31 & 48 & 85.5 \\
\hline Apolipoprotein A-I precursor & В5XВН3 & & & -0.92 & & & & & 32 & 84.7 \\
\hline Apolipoprotein A-I-like & A0A1S3N6U9 & & & & & & 1.65 & 1.66 & 27 & 74.1 \\
\hline Apolipoprotein A-IV & B5XCQ3 & 3.76 & & 4.63 & 6.67 & 4.72 & 6.43 & 6.13 & 11 & 38.4 \\
\hline Apolipoprotein A-IV & B5X8U6 & & & & 2.06 & 1.76 & 1.52 & 1.73 & 17 & 62.7 \\
\hline Apolipoprotein A-IV-like & A0A1S3N6W3 & & & 1.49 & 1.21 & 1.58 & 1.42 & 1.36 & 21 & 61.6 \\
\hline Apolipoprotein Eb-like & A0A1S3RXT3 & & & & -0.99 & & -1.60 & -1.06 & 21 & 54.1 \\
\hline Apolipoprotein Eb-like & A0A1S3M355 & & & & 1.91 & & 2.87 & 2.77 & 11 & 35.2 \\
\hline CD59 glycoprotein-like & A0A1S3QTX5 & & & & 1.07 & & 1.01 & 1.28 & 4 & 48.9 \\
\hline Clusterin & COH9Y2 & & & & 0.70 & & & & 8 & 15.8 \\
\hline Complement $\mathrm{C} 1 \mathrm{q}$ subcomponent subunit $\mathrm{C}$ & $\mathrm{COHB93}$ & & & 2.30 & & & & & 4 & 14.5 \\
\hline Complement C1q-like protein 2 & A0A1S3LRM2 & & & & & & & 0.85 & 7 & 28.1 \\
\hline Complement C1r-A subcomponent-like & A0A1S3RZ46 & & 1.48 & & & 0.90 & & & 7 & 16.1 \\
\hline Complement $\mathrm{C} 1 \mathrm{r}$-A subcomponent-like isoform $\mathrm{X} 2$ & A0A1S3MRC6 & 0.93 & & & & & & & 14 & 22.5 \\
\hline Complement C2-like & A0A1S3NRD5 & & 0.43 & & & & 0.75 & 0.80 & 41 & 52.6 \\
\hline Complement C3-like & A0A1S3L7F1 & & & 0.34 & 0.39 & & 0.25 & & 67 & 30.4 \\
\hline Complement C3-like & A0A1S3ML57 & & & & & 1.00 & & & 9 & 33.3 \\
\hline Complement C4-B & A0A1S3ML18 & & & & & 0.87 & 1.65 & 1.84 & 13 & 49 \\
\hline Complement C4-B-like & A0A1S3NRS7 & 1.01 & & 1.13 & & & 0.80 & 0.84 & 28 & 13.6 \\
\hline Complement C4-like & A0A1S3T028 & 1.26 & & 0.83 & & & & & 23 & 12.4 \\
\hline Complement C4-like & A0A1S3RYT8 & & & 0.80 & & 0.78 & 1.58 & 1.53 & 54 & 32.6 \\
\hline
\end{tabular}


Table 2. Cont.

\begin{tabular}{|c|c|c|c|c|c|c|c|c|c|c|}
\hline Name & Gene & 2 dpi & $3 \mathrm{dpi}$ & $4 \mathrm{dpi}$ & $7 \mathrm{dpi}$ & $9 \mathrm{dpi}$ & $11 \mathrm{dpi}$ & $14 \mathrm{dpi}$ & Peptide Matches & \% Sequence Coverage \\
\hline Complement C4-like & A0A1S3QML7 & & & & & & 1.82 & 1.83 & 35 & 50.1 \\
\hline Complement component C9 & A0A1S3LT49 & 1.24 & & 0.73 & 0.67 & & 0.51 & 0.50 & 23 & 45.3 \\
\hline Complement factor B-like & A0A1S3LZP4 & 1.26 & 0.37 & 1.10 & 0.63 & & 0.63 & & 15 & 22.4 \\
\hline Complement factor B-like & A0A1S3L2E5 & & 0.75 & 0.93 & & 0.59 & 0.63 & 0.85 & 33 & 35.7 \\
\hline Complement factor $\mathrm{H}$-like & A0A1S3KK78 & & 0.39 & & & & 0.31 & 0.40 & 20 & 71.1 \\
\hline Complement factor H-like & A0A1S3QR20 & & & 0.40 & 0.42 & & & & 48 & 50.3 \\
\hline Complement factor H-like & A0A1S3KK91 & & & & 0.87 & & 1.37 & 1.42 & 6 & 32.4 \\
\hline Complement factor I & A0A1S3QGX2 & & 0.59 & 0.93 & 0.75 & 0.64 & 0.85 & 0.72 & 26 & 44.1 \\
\hline Complement factor I-like & A0A1S3QGL8 & & & & & & 0.61 & & 13 & 47.8 \\
\hline Glutathione peroxidase & A0A1S3MM95 & & & & & & 2.78 & 1.72 & 6 & 38.2 \\
\hline $\begin{array}{l}\text { Hemagglutinin/amebocyte aggregation factor-like } \\
\text { isoform X1 }\end{array}$ & A0A1S3MZH7 & & & & & -1.06 & -1.07 & -1.01 & 6 & 38.1 \\
\hline Olfactomedin-4-like & A0A1S3MMF4 & & & & 0.96 & & 1.21 & 0.88 & 7 & 12.4 \\
\hline Olfactomedin-4-like & A0A1S3KM81 & & & & 0.93 & & 1.20 & 0.99 & 9 & 18.3 \\
\hline Plasma protease $\mathrm{C} 1$ inhibitor-like & A0A1S3RGH0 & & & & & & 0.53 & 0.47 & 25 & 39.8 \\
\hline Plasma protease $\mathrm{C} 1$ inhibitor-like & A0A1S3SJI8 & & & & 0.59 & & 0.81 & 0.79 & 14 & 26.2 \\
\hline Properdin-like & A0A1S3LII4 & & & & & 0.42 & 0.31 & 0.39 & 13 & 39.8 \\
\hline Serotransferrin & A0A1S2WYW0 & & & & & 1.50 & & & 82 & 78 \\
\hline Serotransferrin & A0A1S3R1S1 & & & & & & -0.35 & -0.27 & 84 & 78.2 \\
\hline Serotransferrin-1-like & A0A1S3R1U4 & 0.62 & & & & & -0.92 & -0.85 & 25 & 43 \\
\hline Thymosin beta & B5XAM0 & & 2.53 & & & 3.00 & 2.79 & 2.46 & 4 & 76.7 \\
\hline
\end{tabular}




\section{Discussion}

Immune response is an intricate and dynamic phenomenon, which can be stimulated or inhibited by numerous factors often in a context-dependent manner. As a result, the investigation of the host response to AGD is a complex and multi-faceted challenge. Previous studies have taken alternate approaches to the investigation of AGD, with some focusing specifically on lesioned tissue, while others have looked at the entire gill area. In some cases genomic responses were found to be lesion specific, or more pronounced in the lesion [12], while others suggest that examination of the responses only in lesions may fail to account for infiltration of immune factors from surrounding tissue [14]. This study investigated the host immune response across various timepoints from very early sub-clinical disease stages until such point as gill score 2 was achieved in $50 \%$ of fish, in compliance with the HPRA experimental licence. Given that our earliest sampled timepoint was $2 \mathrm{dpi}$ and lesions did not develop until $11 \mathrm{dpi}$, it was therefore essential to utilise a consistent sampling approach to investigate the host proteome response in the gill tissue. Indeed, although lesion specific reactions may not be evident in our study, in the context of investigating the host response from sub-clinical disease stages, the delay between initial inoculation and eventual development of visible lesions necessitates the inclusion of the entire gill. We therefore had the opportunity to gain insight into early stage changes at a protein level across the entire gill and serum.

Innate immunity in fish is the primary defence system, central to their survival from early developmental stages. The complement system is particularly diverse in fish and elements of complement have been shown to be expressed from the early embryonic stage $[38,39]$. The range of complement factors observed to be differentially expressed in serum across various timepoints in this study reflects this diversity. Serum pro-immune complement activity included many factors from both the classic and alternative pathways showing some degree of up-regulation. However, in the gill, immuno-stimulatory complement was limited to the expression of the C4 component and C6 precursor of the complement cascade. $\mathrm{C} 4$ was initially found to be significantly down-regulated at $7 \mathrm{dpi}$ and only eventually up-regulated from $11 \mathrm{dpi}$ and the expression of complement component C6 precursorwas only marginally increased across various timepoints.

Complement factor I (CFI) negatively regulates the complement system by cleavage of the $\mathrm{C} 3 \mathrm{~b}$ and $\mathrm{C} 4 \mathrm{~b}$ complement factors, both of which have been implicated in opsonization, stimulation of antibody response and clearance of immune complexes and apoptotic cells from tissues [40]. No clinical pathologies are associated with up-regulation of CFI and complement factor inactivation by CFI is strongly dependent on appropriate cofactor binding [41]. Therefore, the impact of CFI up-regulation must be investigated in the context of cofactor protein expression. However, the up-regulation of CFI expression, though observed in both tissue types across various timepoints in this study, was much more pronounced in the gill. Complement factor $\mathrm{H}(\mathrm{CFH})$, also a negative regulator of the complement cascade which binds to complement $\mathrm{C} 3 \mathrm{~b}$ blocking the downstream alternative pathway, may be particularly interesting in the context of AGD. In human pathogenic microbe studies pathogen expression of host-like glycans facilitates pathogen binding to complement factor $\mathrm{H}$, which in turn stimulates host immune suppression as a strategy for microbe survival $[42,43]$. Various isoforms of CFH exhibit up-regulation in both tissue types, particularly towards the later stages in this study though expression in the gill is more elevated. The latest timepoint in this study is relatively early in terms of AGD disease progression. Therefore, investigation of the expression of CFI and CFH in fish at later stages of disease could prove interesting in the context of pathogen-derived suppression of the local host immune response.

Properdin stimulates the complement cascade, while clusterin, CD59 and the plasma protease C1 inhibitor inhibit complement [44-46]. In serum, while the expression of properdin, clusterin and both plasma protease inhibitor isoforms showed modest up- 
regulation, CD59 demonstrated a more substantial up-regulation which may point to enhanced cascade inhibition. However, the expressions of these proteins in the serum must be considered in the context of their roles in normal complement regulation and their interactions with the various other complement factors expressed in serum.

Taken together these data suggest that though modest in some cases, a variety of pro-immune factors are up-regulated in response to AGD and suggest an immune response at the systemic level. However, the dearth of complement factor expression, and the inhibitory action of those most substantially up-regulated suggest a local suppression of the complement cascade within gill tissue. It is noteworthy however, that previous studies have either failed to detect differences in serum complement factor activity [47], or have been unable to detect any discernible effects of variable complement expression in response to P. perurans colonisation [48]. Therefore, the significance of the complement cascade in the host response to AGD remains unclear. However, a recent genome mapping study implicated the C4 gene as one of three genes involved in disease resistance in AGD [49], and genetic screening of susceptible versus resistant fish also demonstrated an upregulation of plasma protease $\mathrm{C} 1$ inhibitor in resistant gill samples [50]. Kube et al. also demonstrated that resistance after one $P$. perurans infection was attributable to an innate response, in contrast to resistance after multiple infections [8]. In the context of these previous findings, our data may support the role of complement in the development of disease resistance in AGD.

Apolipoproteins, though traditionally associated with lipoprotein structure and metabolism, are emerging as significant components in innate immunity. The biological significance of apolipoprotein subtypes is varied and context-dependent. Apolipoprotein A-I (ApoA-I), one of the most abundant apolipoproteins in fish [51], and Apolipoprotein E (ApoE) have both been implicated in the binding and neutralization of bacterial lipopolysaccharide (LPS) in mammalian lung. Furthermore, ApoE can facilitate bacterial endocytosis and ApoA-I can stimulate Toll Like Receptor (TLR) pathways to promote further immune responses [52]. Apolipoprotein C-I (ApoC-I) facilitates the LPS induced inflammatory response in mouse models [53] and is down-regulated in severe sepsis [54]. Conversely, apolipoprotein A-IV (ApoA-IV) has an inhibitory effect on integrin regulated platelet adhesion [55], which can in turn negatively impact on leukocyte recruitment to the site of infection or injury [56]. Furthermore ApoA-IV has a negative impact on eosinophil induced inflammation and ApoA-I acts as a negative acute phase protein, which interferes with T-cell signalling and reduces inflammation. These proteins are considered sufficiently potent such that their use as therapeutic agents to reduce hyper responsiveness in airway allergies is being investigated [57]. Interpretation of apolipoprotein expression though inherently complex due to the diversity of roles, is further complicated by the finding that expression in response to bacterial infection in channel catfish was found to be highly pathogen-dependent [58].

In both the gill and serum, with the exception of the increase in expression of ApoA-I and ApoEb from $7 \mathrm{dpi}$, the differential expression values obtained for the other apolipoprotein isoforms may be indicative of an elevated inhibition of leukocyte recruitment and a reduction of the inflammatory response. Up-regulation of the pro-inflammatory cytokines tumour necrosis factor $\alpha(\mathrm{TNF} \alpha)$ and Interleukin 6 (IL-6) have previously been shown to decrease ApoA-IV expression at both the gene and protein level in obesity models in mice [59]. While upregulation of $\mathrm{TNF} \alpha$ gene expression was previously demonstrated particularly in lesions [14], another study found TNF $\alpha$ isoforms to be unchanged or downregulated in AGD-associated gill lesions at the gene level [60]. This is consistent with the lack of significant expression of pro-inflammatory cytokines detected at the protein level in either gill or serum in this study. Here, the elevated expression of ApoA-IV, evident in both gill and serum may be due to the loss of the negative regulation afforded by the pro-inflammatory cytokines. Other studies have found differential protein expression of some apolipoproteins $[18,20]$, however this is the first study to report such a diverse range of apolipoprotein isoforms demonstrating differential expression in AGD. Indeed, the con- 
sistencies between gill and serum fold change trends observed across various timepoints in this study suggest the importance of these proteins in the host response, however the nature of the roles of apolipoproteins requires further investigation.

Within the gill, many other factors involved in host immune response, inflammation, and immune signalling were found to be differentially expressed. Histone H2A which acts as an antimicrobial peptide (AMP) [61] showed no significant activity until $14 \mathrm{dpi}$, at which point it was markedly down-regulated. Eosinophil Peroxidase (EPX) which can oxidise halide ions to form bactericidal reactive oxygen species $[62,63]$ was downregulated from $4 \mathrm{dpi}$, which aside from potentially impacting on bactericidal ability, may also impact negatively on macrophage phagocytosis [64]. The marked down-regulation of leukocyte elastase inhibitor which itself impedes the action of proteolytic enzymes and inflammatory caspases as a mechanism of protection against aberrant protein degradation [65] may negatively impact on neutrophil survival, as previously demonstrated in mouse models [66].

Granulins which activate the TLR 9 [67], the leucine-rich repeat-containing protein 59 (LRRC 59) which has a role in TLR trafficking from the ER [68] and 1-phosphatidylinositol 4,5-bisphosphate phosphodiesterase delta-1 which catalyses IP3 and DAG production [69] all exhibited decreased expression in this study. The expressions of heterogeneous nuclear ribonucleoprotein $\mathrm{A} 0$ and Nuclear Receptor Coactivator 5, both with roles in the binding and endocytosis of bacterial DNA [70] and Ras-related protein Rab-11A, the downregulation of which has previously been implicated in the vascular leakage observed in pulmonary microvessels during microbial sepsis [71], were also found to be reduced. Dicarbonyl and L-xylulose reductase catalyses the reduction of Reactive Carbonyl Species (RCS). Down-regulation of this enzyme as observed in our current study from 7 dpi results in dicarbonyl stress which can impact protein folding and mitochondrial dysfunction and has been identified as both a promoter and end product of oxidative stress [72]. In a recent human diabetes study, markers of dicarbonyl stress were associated with complement modulation though the biological impact was found to be stress marker specific [73]. Furthermore Magnesium transporter protein 1 (MGT1) is essential for magnesium homeostasis in eurkaryotic cells and $\mathrm{Mg}^{2+}$ has been reported to act as a second messenger in immunity [74]. A deficiency of MGT1, as observed here from $7 \mathrm{dpi}$, alters immune glycoprotein levels [75] and has been linked to impaired expression of programmed cell death and natural killer activating receptors in T-cells [76]. The functional diversity of these proteins and their downregulation demonstrates the range of immune functions negatively affected by P. perurans colonisation.

The lacklustre early immune response in the gill was somewhat counteracted by the discussed elevation of complement factor 4 at $11 \mathrm{dpi}$, ApoA-I at $7 \mathrm{dpi}$ and the cationdependent mannose-6-phosphate receptor which has a role in trafficking of lysosomal enzymes to the lysosome [77] at $4 \mathrm{dpi}$. Furthermore, the Zymogen granule membrane protein 16, a secretory lectin found in mucus which binds to and causes the aggregation of Gram-positive bacteria in the mouse gut thus retarding bacterial migration through mucus and into tissue [78], was significantly elevated by $14 \mathrm{dpi}$. Indeed an increase in mucus secretion is a characteristic feature of AGD, and although the fold changes were modest, the increase in the expression of several mucin protein isoforms observed in this study may pre-empt much larger expression increases at later stages of infection as suggested by results obtained from a genomic study showing up-regulation of mucin gene expression at 14 and 21 dpi [18].

In addition to the myriad immune factors which demonstrated differential expression in response to $P$. perurans colonisation, in the gill some proteins with roles in wound healing also exhibited differential expression upon disease progression. Polypyrimidine tract binding proteins have long been associated with cancer metastases [79], but have also been linked to the establishment of focal adhesions, a process which has been shown to be key in the dynamics of wound healing [80]. The calpains which belong to a ubiquitously expressed family of calcium-dependent cysteine proteases have been implicated in numerous cellular processes including apoptosis, bacterial clearance and wound healing [81-83]. Furthermore, 
members of the aminoacyl tRNA synthase complex-interacting multifunctional protein family have been shown to be secreted from macrophages at the site of tissue injury in response to $T N F \alpha$, and have been implicated in wound healing by stimulation of fibroblast proliferation and collagen synthesis [84]. Taken together, the expression profiles of these proteins demonstrate an enhanced wound response only at the latest disease stage in this study (14 dpi), the point at which the most pronounced and numerous gross lesions are in evidence.

In the serum almost half of those proteins exhibiting significant differential expression across the various time points were found to have immune-related functions. Most, as discussed, were members of the apolipoprotein family, or the complement cascade. In addition thymosin beta a potent bacteriostatic agent which has been shown to be involved in the antimicrobial immune response in teleosts [85] and may also have a role in the acceleration of wound healing [86] was consistently up-regulated in the serum at the later timepoints. Glutathione peroxidase, a cellular anti-oxidant which also regulates the antiviral immune response [87] was found here to be up-regulated in the serum but not the gill, which supports the findings of a previous study which demonstrated enhanced expression of peroxidases in serum but not mucus of AGD-affected salmon [18].

Hemagglutinin/amebocyte aggregation factor which has an established role in the mechanism of self/non-self-recognition [88] was down-regulated in serum. Transferrin is a protein associated with the innate immune response, which sequesters iron thus creating a low iron environment which is not conducive to bacterial survival [89]. Aside from a peak at $9 \mathrm{dpi}$, expression of the transferrins remained low or expression was decreased. Furthermore an increased expression of Olfactomedin 4 as observed in the serum has been linked to immune suppression and bacterial load in mice studies, and has been shown to suppress inflammation and immune cell infiltration [90].

In the serum an early immune response was observable. While further complement factor expression was detectable at the later time points, suppression of pro-immune factors and stimulation of immune-inhibitory factors became more apparent from $9 \mathrm{dpi}$. Conversely in the gill the traditional immune factors associated with classic early stage response showed little or no reaction to gill colonisation by P. perurans, while some immune specific inhibitory factors appeared stimulated, and other peripheral pathways involved in signalling and cell migration were depressed upon infection. Comparisons have previously been made between parasite induced host immunomodulation observed in helminthic parasite infection and immune gene expression in AGD [13]. Mechanisms of parasite immunosuppression appear to be varied and the impact profound [91]. The wide variety of factors negatively impacting on the immune response in this study support the concept of a pathogen-derived suppression of host response, as suggested in previous genomic studies [92].

\section{Conclusions}

Investigation of AGD in salmon gill and serum, at a proteomic level, across various subclinical and clinical time points has provided a novel insight into protein expression in very early disease stages. The results obtained demonstrated a lack of a robust classical immune response before $7 \mathrm{dpi}$ in the gill, and many of the differentially expressed proteins identified have suppressive roles in the immune response and were not previously highlighted in the context of AGD. Conversely, some of the proteins differentially expressed in serum initially exhibited a positive immune response with some immune suppression evident at later stages. Taken together, the pro-immune trend observed in serum and the diversity of down-regulated proteins in the gill may indicate a local pathogen-derived suppression of host immune response. This study has identified many proteins which may have significant roles in the host response to AGD and may contribute to our understanding of the underlying pathology of the disease at both the local and systemic levels in particular during sub-clinical stages. 
Supplementary Materials: The following are available online at https:/ / www.mdpi.com/article/10 .3390 / microorganisms 9040746 /s1, Figure S1: Immune system process pathway analysis of serum samples using the Cluego app (v2.5.7) in Cytoscape (v1.5.7) demonstrated upregulation of proimmune pathways at 3, 4 and $7 \mathrm{dpi}(\mathrm{A}-\mathrm{C})$. Immune enrichment was absent at $9 \mathrm{dpi}$, but was restored by $11 \mathrm{dpi}(\mathrm{D})$. At $11 \mathrm{dpi}$ and $14 \mathrm{dpi}$, the pro-immune pathway upregulation was accompanied by an elevation of various pathways which negatively regulate immunity $(\mathrm{D}, \mathrm{E})$. A $p$ value of $<0.05$ and kappa coefficient of 0.4 were considered as threshold values. The size of the nodes reflects the statistical significance of the terms. No immune pathway enrichment was detected at any timepoint in gill samples.

Author Contributions: Conceptualization: E.M. and I.O.; Methodology: M.M. and E.D.; Formal Analysis: M.M. and E.D.; Investigation: M.M.; Writing-Original Draft Preparation: M.M.; WritingReview and Editing: M.M., E.D., I.O., E.M.; Visualization: M.M.; Supervision: E.M. and I.O.; Project Administration: E.M.; Funding Acquisition: E.M. All authors have read and agreed to the published version of the manuscript.

Funding: This material is based upon research supported by the Department of Agriculture, Food and the Marine under the Grant award No. [DAFM Project Code 15/S/745].

Institutional Review Board Statement: The study was conducted according to the guidelines of the Declaration of Helsinki, and approved by the Animal Research Ethics Committee of Galway Mayo Institute of Technology on 23 October 2017.

Informed Consent Statement: Not applicable.

Data Availability Statement: Data are available via ProteomeXchange with identifier PXD022101.

Acknowledgments: We gratefully acknowledge the technical support of the staff at the Agri-food \& Biosciences Institute, Northern Ireland and the Marine Institute Galway.

Conflicts of Interest: The authors declare no conflict of interest.

\section{References}

1. Munday, B.L. Diseases of salmonids. In Proceedings of the Workshop on Diseases of Australian Fish and Shellfish; Australian Fish Health Reference Laboratory: Regional Veterinary Laboratory: Benalla, Australia, 1986; pp. 127-141.

2. Rodger, H.D. Amoebic gill disease (AGD) in farmed salmon (Salmo salar) in Europe. Fish Vet. J. 2014, 14, 16-27.

3. Taylor, R.S.; Muller, W.J.; Cook, M.T.; Kube, P.D.; Elliott, N.G. Gill observations in Atlantic salmon (Salmo salar, L.) during repeated amoebic gill disease (AGD) field exposure and survival challenge. Aquaculture 2009, 290, 1-8. [CrossRef]

4. Oldham, T.; Rodger, H.; Nowak, B.F. Incidence and distribution of amoebic gill disease (AGD)—An epidemiological review. Aquaculture 2016, 457, 35-42. [CrossRef]

5. Adams, M.B.; Nowak, B.F. Amoebic gill disease: Sequential pathology in cultured Atlantic salmon, Salmo salar L. J. Fish Dis. 2003, 26, 601-614. [CrossRef]

6. Roberts, S.D.; Powell, M.D. Freshwater bathing alters the mucous layer of marine Atlantic salmon Salmo salar L. J. Fish Biol. 2008, 72, 1864-1870. [CrossRef]

7. Martinsen, K.H.; Thorisdottir, A.; Lillehammer, M. Effect of hydrogen peroxide as treatment for amoebic gill disease in Atlantic salmon (Salmo salar L.) in different temperatures. Aquac. Res. 2018, 49, 1733-1739. [CrossRef]

8. Kube, P.D.; Taylor, R.S.; Elliott, N.G. Genetic variation in parasite resistance of Atlantic salmon to amoebic gill disease over multiple infections. Aquaculture 2012, 364-365, 165-172. [CrossRef]

9. Young, N.D.; Cooper, G.A.; Nowak, B.F.; Koop, B.F.; Morrison, R.N. Coordinated down-regulation of the antigen processing machinery in the gills of amoebic gill disease-affected Atlantic salmon (Salmo salar L.). Mol. Immunol. 2008, 45, 2581-2597. [CrossRef]

10. Loo, G.H.; Sutton, D.L.; Schuller, K.A. Cloning and functional characterisation of a peroxiredoxin 1 (NKEF A) cDNA from Atlantic salmon (Salmo salar) and its expression in fish infected with Neoparamoeba perurans. Fish Shellfish Immunol. 2012, 32, 1074-1082. [CrossRef]

11. Bridle, A.R.; Morrison, R.N.; Cupit Cunningham, P.M.; Nowak, B.F. Quantitation of immune response gene expression and cellular localisation of interleukin-1beta mRNA in Atlantic salmon, Salmo salar L., affected by amoebic gill disease (AGD). Vet. Immunol. Immunopathol. 2006, 114, 121-134. [CrossRef]

12. Marcos-López, M.; Calduch-Giner, J.A.; Mirimin, L.; MacCarthy, E.; Rodger, H.D.; O'Connor, I.; Sitjà-Bobadilla, A.; Pérez-Sánchez, J.; Piazzon, M.C. Gene expression analysis of Atlantic salmon gills reveals mucin 5 and interleukin $4 / 13$ as key molecules during amoebic gill disease. Sci. Rep. 2018, 8, 13689. [CrossRef]

13. Benedicenti, O.; Collins, C.; Wang, T.; McCarthy, U.; Secombes, C.J. Which Th pathway is involved during late stage amoebic gill disease? Fish Shellfish Immunol. 2015, 46, 417-425. [CrossRef] [PubMed] 
14. Pennacchi, Y.; Leef, M.J.; Crosbie, P.B.B.; Nowak, B.F.; Bridle, A.R. Evidence of immune and inflammatory processes in the gills of AGD-affected Atlantic salmon, Salmo salar L. Fish Shellfish Immunol. 2014, 36, 563-570. [CrossRef]

15. Nowak, B.; Cadoret, K.; Feist, S.W.; Bean, T.P. Laser-capture dissection and immunohistochemistry reveals chloride and mucouscell specific gene expression in gills of seawater acclimated Atlantic salmon Salmo salar. J. Fish Biol. 2013, 83, $1459-1467$. [CrossRef]

16. Gross, K.A.; Powell, M.D.; Butler, R.; Morrison, R.N.; Nowak, B.F. Changes in the innate immune response of Atlantic salmon, Salmo salar L., exposed to experimental infection with Neoparamoeba sp. J. Fish Dis. 2005, 28, 293-299. [CrossRef]

17. Valdenegro-Vega, V.A.; Polinski, M.; Bridle, A.; Crosbie, P.; Leef, M.; Nowak, B.F. Effects of single and repeated infections with Neoparamoeba perurans on antibody levels and immune gene expression in Atlantic salmon (Salmo salar). Fish Shellfish Immunol. 2015, 42, 522-529. [CrossRef]

18. Marcos-López, M.; Espinosa Ruiz, C.; Rodger, H.D.; O’Connor, I.; MacCarthy, E.; Esteban, M.Á. Local and systemic humoral immune response in farmed Atlantic salmon (Salmo salar L.) under a natural amoebic gill disease outbreak. Fish Shellfish Immunol. 2017, 66, 207-216. [CrossRef]

19. Rodrigues, P.M.; Silva, T.S.; Dias, J.; Jessen, F. PROTEOMICS in aquaculture: Applications and trends. J. Proteom. 2012, 75, 4325-4345. [CrossRef]

20. Valdenegro-Vega, V.A.; Crosbie, P.; Bridle, A.; Leef, M.; Wilson, R.; Nowak, B.F. Differentially expressed proteins in gill and skin mucus of Atlantic salmon (Salmo salar) affected by amoebic gill disease. Fish Shellfish Immunol. 2014, 40, 69-77. [CrossRef]

21. Magdeldin, S.; Enany, S.; Yoshida, Y.; Xu, B.; Zhang, Y.; Zureena, Z.; Lokamani, I.; Yaoita, E.; Yamamoto, T. Basics and recent advances of two dimensional- polyacrylamide gel electrophoresis. Clin. Proteom. 2014, 11, 16. [CrossRef]

22. Hernandez-Valladares, M.; Aasebø, E.; Mjaavatten, O.; Vaudel, M.; Bruserud, Ø.; Berven, F.; Selheim, F. Reliable FASP-based procedures for optimal quantitative proteomic and phosphoproteomic analysis on samples from acute myeloid leukemia patients. Biol. Proced. Online 2016, 18, 13. [CrossRef] [PubMed]

23. Wang, W.-Q.; Jensen, O.N.; Møller, I.M.; Hebelstrup, K.H.; Rogowska-Wrzesinska, A. Evaluation of sample preparation methods for mass spectrometry-based proteomic analysis of barley leaves. Plant Methods 2018, 14, 72. [CrossRef] [PubMed]

24. Wiśniewski, J.R.; Zougman, A.; Nagaraj, N.; Mann, M. Universal sample preparation method for proteome analysis. Nat. Methods 2009, 6, 359-362. [CrossRef] [PubMed]

25. Crosbie, P.B.B.; Bridle, A.R.; Cadoret, K.; Nowak, B.F. In vitro cultured Neoparamoeba perurans causes amoebic gill disease in Atlantic salmon and fulfils Koch's postulates. Int. J. Parasitol. 2012, 42, 511-515. [CrossRef]

26. Downes, J.K.; Henshilwood, K.; Collins, E.M.; Ryan, A.; O'Connor, I.; Rodger, H.D.; MacCarthy, E.; Ruane, N.M. A longitudinal study of amoebic gill disease on a marine Atlantic salmon farm utilising a real-time PCR assay for the detection of Neoparamoeba perurans. Aquac. Environ. Interact. 2015, 7, 239-251. [CrossRef]

27. Rappsilber, J.; Ishihama, Y.; Mann, M. Stop and Go Extraction Tips for Matrix-Assisted Laser Desorption/Ionization, Nanoelectrospray, and LC/MS Sample Pretreatment in Proteomics. Anal. Chem. 2003, 75, 663-670. [CrossRef] [PubMed]

28. Cox, J.; Mann, M. MaxQuant enables high peptide identification rates, individualized p.p.b.-range mass accuracies and proteomewide protein quantification. Nat. Biotechnol. 2008, 26, 1367-1372. [CrossRef]

29. Tyanova, S.; Temu, T.; Cox, J. The MaxQuant computational platform for mass spectrometry-based shotgun proteomics. Nat. Protoc. 2016, 11, 2301-2319. [CrossRef]

30. Cox, J.; Neuhauser, N.; Michalski, A.; Scheltema, R.A.; Olsen, J.V.; Mann, M. Andromeda: A Peptide Search Engine Integrated into the MaxQuant Environment. J. Proteome Res. 2011, 10, 1794-1805. [CrossRef]

31. Cox, J.; Hein, M.Y.; Luber, C.A.; Paron, I.; Nagaraj, N.; Mann, M. Accurate Proteome-wide Label-free Quantification by Delayed Normalization and Maximal Peptide Ratio Extraction, Termed MaxLFQ. Mol. Cell. Proteom. 2014, 13, 2513-2526. [CrossRef]

32. Perez-Riverol, Y.; Csordas, A.; Bai, J.; Bernal-Llinares, M.; Hewapathirana, S.; Kundu, D.J.; Inuganti, A.; Griss, J.; Mayer, G.; Eisenacher, M.; et al. The PRIDE database and related tools and resources in 2019: Improving support for quantification data. Nucleic Acids Res. 2019, 47, D442-D450. [CrossRef] [PubMed]

33. Bindea, G.; Mlecnik, B.; Hackl, H.; Charoentong, P.; Tosolini, M.; Kirilovsky, A.; Fridman, W.-H.; Pagès, F.; Trajanoski, Z.; Galon, J. ClueGO: A Cytoscape plug-in to decipher functionally grouped gene ontology and pathway annotation networks. Bioinformatics 2009, 25, 1091-1093. [CrossRef] [PubMed]

34. Bindea, G.; Galon, J.; Mlecnik, B. CluePedia Cytoscape plugin: Pathway insights using integrated experimental and in silico data. Bioinformatics 2013, 29, 661-663. [CrossRef] [PubMed]

35. Shannon, P.; Markiel, A.; Ozier, O.; Baliga, N.S.; Wang, J.T.; Ramage, D.; Amin, N.; Schwikowski, B.; Ideker, T. Cytoscape: A Software Environment for Integrated Models of Biomolecular Interaction Networks. Genome Res. 2013, 13, 2498-2504. [CrossRef]

36. Ashburner, M.; Ball, C.A.; Blake, J.A.; Botstein, D.; Butler, H.; Cherry, J.M.; Davis, A.P.; Dolinski, K.; Dwight, S.S.; Eppig, J.T.; et al. Gene Ontology: Tool for the unification of biology. The Gene Ontology Consortium. Nat. Genet. 2000, 25, 25-29. [CrossRef]

37. The Gene Ontology Consortium. The Gene Ontology Resource: 20 years and still GOing strong. Nucleic Acids Res. 2019, 47, D330-D338. [CrossRef]

38. Magnadóttir, B. Innate immunity of fish (overview). Fish Shellfish Immunol. 2006, 20, 137-151. [CrossRef]

39. Løvoll, M.; Johnsen, H.; Boshra, H.; Bøgwald, J.; Sunyer, J.O.; Dalmo, R.A. The ontogeny and extrahepatic expression of complement factor C3 in Atlantic salmon (Salmo salar). Fish Shellfish Immunol. 2007, 23, 542-552. [CrossRef]

40. Noris, M.; Remuzzi, G. Overview of Complement Activation and Regulation. Semin. Nephrol. 2013, 33, 479-492. [CrossRef] 
41. Yoshida, Y.; Kato, H.; Ikeda, Y.; Nangaku, M. Pathogenesis of Atypical Hemolytic Uremic Syndrome. J. Atheroscler. Thromb. 2019, 26, 99-110. [CrossRef] [PubMed]

42. Meri, T.; Amdahl, H.; Lehtinen, M.J.; Hyvärinen, S.; McDowell, J.V.; Bhattacharjee, A.; Meri, S.; Marconi, R.; Goldman, A.; Jokiranta, T.S. Correction: Microbes Bind Complement Inhibitor Factor H via a Common Site. PLoS Pathog. 2013, 9. [CrossRef]

43. Józsi, M. Factor H Family Proteins in Complement Evasion of Microorganisms. Front. Immunol. 2017, 8, 571. [CrossRef]

44. Hourcade, D.E. The Role of Properdin in the Assembly of the Alternative Pathway C3 Convertases of Complement. J. Biol. Chem. 2006, 281, 2128-2132. [CrossRef] [PubMed]

45. Chauhan, A.K.; Moore, T.L. Presence of plasma complement regulatory proteins clusterin (Apo J) and vitronectin (S40) on circulating immune complexes (CIC). Clin. Exp. Immunol. 2006, 145, 398-406. [CrossRef]

46. Morgan, P. Chapter 34-CD59. In Factsbook, 2nd ed.; Barnum, S., Schein, T., Eds.; Academic Press: Cambridge, MA, USA, 2018; pp. 361-367. ISBN 978-0-12-810420-0.

47. Powell, M.D.; Leef, M.J.; Roberts, S.D.; Jones, M.A. Neoparamoebic gill infections: Host response and physiology in salmonids. J. Fish Biol. 2008, 73, 2161-2183. [CrossRef]

48. Chalmers, L.; Taylor, J.F.; Roy, W.; Preston, A.C.; Migaud, H.; Adams, A. A comparison of disease susceptibility and innate immune response between diploid and triploid Atlantic salmon (Salmo salar) siblings following experimental infection with Neoparamoeba perurans, causative agent of amoebic gill disease. Parasitology 2017, 144, 1229-1242. [CrossRef] [PubMed]

49. Aslam, M.L.; Boison, S.A.; Lillehammer, M.; Norris, A.; Gjerde, B. Genome-wide association mapping and accuracy of predictions for amoebic gill disease in Atlantic salmon (Salmo salar). Sci. Rep. 2020, 10, 1-9. [CrossRef]

50. Robledo, D.; Hamilton, A.; Gutiérrez, A.P.; Bron, J.E.; Houston, R.D. Characterising the mechanisms underlying genetic resistance to amoebic gill disease in Atlantic salmon using RNA sequencing. BMC Genom. 2020, 21, 271. [CrossRef]

51. Dietrich, M.A.; Adamek, M.; Bilinska, B.; Hejmej, A.; Steinhagen, D.; Ciereszko, A. Characterization, expression and antibacterial properties of apolipoproteins A from carp (Cyprinus carpio L.) seminal plasma. Fish Shellfish Immunol. 2014, 41, 389-401. [CrossRef]

52. Figueroa, D.M.; Gordon, E.M.; Yao, X.; Levine, S.J. Chapter 13-Apolipoproteins as context-dependent regulators of lung inflammation. In Mechanisms and Manifestations of Obesity in Lung Disease; Johnston, R.A., Suratt, B.T., Eds.; Academic Press: Cambridge, MA, USA, 2019; pp. 301-326. ISBN 978-0-12-813553-2.

53. Westerterp, M.; Berbeée, J.F.; Pires, N.M.M.; Van Mierlo, G.J.D.; Kleemann, R.; Romijn, J.A.; Havekes, L.M.; Rensen, P.C.N. Apolipoprotein C-I Is Crucially Involved in Lipopolysaccharide-Induced Atherosclerosis Development in Apolipoprotein E-Knockout Mice. Circulation 2007, 116, 2173-2181. [CrossRef]

54. Berbée, J.F.P.; van der Hoogt, C.C.; de Haas, C.J.C.; van Kessel, K.P.M.; Dallinga-Thie, G.M.; Romijn, J.A.; Havekes, L.M.; van Leeuwen, H.J.; Rensen, P.C.N. Plasma apolipoprotein CI correlates with increased survival in patients with severe sepsis. Intensive Care Med. 2008, 34, 907-911. [CrossRef]

55. Xu, X.R.; Wang, Y.; Adili, R.; Ju, L.; Spring, C.M.; Jin, J.W.; Yang, H.; Neves, M.A.D.; Chen, P.; Yang, Y.; et al. Apolipoprotein A-IV binds $\alpha \mathrm{Ilb} \beta 3$ integrin and inhibits thrombosis. Nat. Commun. 2018, 9, 3608. [CrossRef] [PubMed]

56. Vowinkel, T.; Mori, M.; Krieglstein, C.F.; Russell, J.; Saijo, F.; Bharwani, S.; Turnage, R.H.; Davidson, W.S.; Tso, P.; Granger, D.N.; et al. Apolipoprotein A-IV inhibits experimental colitis. J. Clin. Investig. 2004, 114, 260-269. [CrossRef] [PubMed]

57. Roula, D.; Theiler, A.; Luschnig, P.; Sturm, G.J.; Tomazic, P.V.; Marsche, G.; Heinemann, A.; Sturm, E.M. Apolipoprotein A-IV acts as an endogenous anti-inflammatory protein and is reduced in treatment-naïve allergic patients and allergen-challenged mice. Allergy 2020, 75, 392-402. [CrossRef]

58. Yang, Y.; Fu, Q.; Zhou, T.; Li, Y.; Liu, S.; Zeng, Q.; Wang, X.; Jin, Y.; Tian, C.; Qin, Z.; et al. Analysis of apolipoprotein genes and their involvement in disease response of channel catfish after bacterial infection. Dev. Comp. Immunol. 2017, 67, 464-470. [CrossRef] [PubMed]

59. Li, X.; Xu, M.; Liu, M.; Ji, Y.; Li, Z. TNF-alpha and IL-6 inhibit apolipoprotein A-IV production induced by linoleic acid in human intestinal Caco2 cells. J. Inflamm. 2015, 12, 22. [CrossRef] [PubMed]

60. Morrison, R.N.; Zou, J.; Secombes, C.J.; Scapigliati, G.; Adams, M.B.; Nowak, B.F. Molecular cloning and expression analysis of tumour necrosis factor-alpha in amoebic gill disease (AGD)-affected Atlantic salmon (Salmo salar L.). Fish Shellfish Immunol. 2007, 23, 1015-1031. [CrossRef] [PubMed]

61. Sathyan, N.; Philip, R.; Chaithanya, E.R.; Kumar, P.R.A.; Sanjeevan, V.N.; Singh, I.S.B. Characterization of Histone H2A Derived Antimicrobial Peptides, Harriottins, from Sicklefin Chimaera Neoharriotta pinnata (Schnakenbeck, 1931) and Its Evolutionary Divergence with respect to CO1 and Histone H2A. ISRN Mol. Biol. 2013, 2013, 930216. [CrossRef]

62. Borelli, V.; Vita, F.; Shankar, S.; Soranzo, M.R.; Banfi, E.; Scialino, G.; Brochetta, C.; Zabucchi, G. Human Eosinophil Peroxidase Induces Surface Alteration, Killing, and Lysis of Mycobacterium tuberculosis. Infect. Immun. 2003, 71, 605-613. [CrossRef]

63. Allen, R.C.; Henery, M.L.; Allen, J.C.; Hawks, R.J.; Stephens, J.T. Myeloperoxidase and Eosinophil Peroxidase Inhibit Endotoxin Activity and Increase Mouse Survival in a Lipopolysaccharide Lethal Dose 90\% Model. J. Immunol. Res. 2019, 2019, 1-10. [CrossRef]

64. Lefkowitz, D.L.; Lincoln, J.A.; Howard, K.R.; Stuart, R.; Lefkowitz, S.S.; Allen, R.C. Macrophage-Mediated Candidacidal Activity is Augmented by Exposure to Eosinophil Peroxidase: A Paradigm for Eosinophil-Macrophage Interaction. Inflammation 1997, 21, 159-172. [CrossRef] [PubMed]

65. Choi, Y.J.; Kim, S.; Choi, Y.; Nielsen, T.B.; Yan, J.; Lu, A.; Ruan, J.; Lee, H.-R.; Wu, H.; Spellberg, B.; et al. SERPINB1-mediated checkpoint of inflammatory caspase activation. Nat. Immunol. 2019, 20, 276-287. [CrossRef] 
66. Burgener, S.S.; Baumann, M.; Basilico, P.; Remold-O'Donnell, E.; Touw, I.P.; Benarafa, C. Myeloid conditional deletion and transgenic models reveal a threshold for the neutrophil survival factor Serpinb1. Biol. Chem. 2016, 397, 897-905. [CrossRef]

67. Park, B.; Buti, L.; Lee, S.; Matsuwaki, T.; Spooner, E.; Brinkmann, M.M.; Nishihara, M.; Ploegh, H.L. Granulin Is a Soluble Cofactor for Toll-like Receptor 9 Signaling. Immunity 2011, 34, 505-513. [CrossRef]

68. Tatematsu, M.; Funami, K.; Ishii, N.; Seya, T.; Obuse, C.; Matsumoto, M. LRRC59 Regulates Trafficking of Nucleic Acid-Sensing TLRs from the Endoplasmic Reticulum via Association with UNC93B1. J. Immunol. 2015, 195, 4933-4942. [CrossRef]

69. Singh, B.K.; Kambayashi, T. The Immunomodulatory Functions of Diacylglycerol Kinase ל. Front. Cell Dev. Biol. 2016, 4, 96. [CrossRef] [PubMed]

70. Iliev, D.B.; Skjæveland, I.; Jørgensen, J.B. CpG oligonucleotides bind TLR9 and RRM-Containing proteins in Atlantic Salmon (Salmo salar). BMC Immunol. 2013, 14, 12. [CrossRef] [PubMed]

71. Yan, Z.; Wang, Z.-G.; Segev, N.; Hu, S.; Minshall, R.D.; Dull, R.O.; Zhang, M.; Malik, A.B.; Hu, G. Rab11a Mediates Vascular Endothelial-Cadherin Recycling and Controls Endothelial Barrier Function. Arter. Thromb. Vasc. Biol. 2016, 36, 339-349. [CrossRef] [PubMed]

72. Rabbani, N.; Thornalley, P.J. Dicarbonyl stress in cell and tissue dysfunction contributing to ageing and disease. Biochem. Biophys. Res. Commun. 2015, 458, 221-226. [CrossRef] [PubMed]

73. Xin, Y.; Hertle, E.; Van Der Kallen, C.J.H.; Schalkwijk, C.G.; Stehouwer, C.D.A.; Van Greevenbroek, M.M.J. Associations of dicarbonyl stress with complement activation: The CODAM study. Diabetologia 2020, 63, 1032-1042. [CrossRef] [PubMed]

74. Schmitz, C.; Perraud, A.-L. Chapter 26-Magnesium and the Immune Response. In Molecular, Genetic, and Nutritional Aspects of Major and Trace Minerals; Collins, J.F., Ed.; Academic Press: Boston, MA, USA, 2017; pp. 319-331. ISBN 978-0-12-802168-2.

75. Matsuda-Lennikov, M.; Biancalana, M.; Zou, J.; Ravell, J.C.; Zheng, L.; Kanellopoulou, C.; Jiang, P.; Notarangelo, G.; Jing, H.; Masutani, E.; et al. Magnesium transporter 1 (MAGT1) deficiency causes selective defects in N-linked glycosylation and expression of immune-response genes. J. Biol. Chem. 2019, 294, 13638-13656. [CrossRef] [PubMed]

76. Diao, B.; Huang, X.; Guosong, L.; Yang, C.; Liu, G.; Chengying, Y.; Wu, Y. MAGT1-mediated disturbance of Mg2+ homeostasis lead to exhausted of HBV-infected NK and CD8+ T cells. Sci. Rep. 2017, 7, 1-7. [CrossRef] [PubMed]

77. Ludwig, T.; Rüther, U.; Metzger, R.; Copeland, N.G.; Jenkins, N.A.; Lobel, P.; Hoflack, B. Gene and pseudogene of the mouse cation-dependent mannose 6-phosphate receptor. Genomic organization, expression, and chromosomal localization. J. Biol. Chem. 1992, 267, 12211-12219. [CrossRef]

78. Bergström, J.H.; Birchenough, G.M.H.; Katona, G.; Schroeder, B.O.; Schütte, A.; Ermund, A.; Johansson, M.E.V.; Hansson, G.C. Gram-positive bacteria are held at a distance in the colon mucus by the lectin-like protein ZG16. Proc. Natl. Acad. Sci. USA 2016, 113, 13833-13838. [CrossRef]

79. Hou, P.; Chen, F.; Yong, H.; Lin, T.; Li, J.; Pan, Y.; Jiang, T.; Li, M.; Chen, Y.; Song, J.; et al. PTBP3 contributes to colorectal cancer growth and metastasis via translational activation of HIF-1 $\alpha$. J. Exp. Clin. Cancer Res. 2019, 38, 301. [CrossRef]

80. Babic, I.; Sharma, S.; Black, D.L. A Role for Polypyrimidine Tract Binding Protein in the Establishment of Focal Adhesions. Mol. Cell. Biol. 2009, 29, 5564-5577. [CrossRef]

81. Momeni, H.R.; Kanje, M. The calpain inhibitor VI prevents apoptosis of adult motor neurons. Neuroreport 2005, 16, 1065-1068. [CrossRef]

82. Kumar, V.; Everingham, S.; Hall, C.; Greer, P.A.; Craig, A.W.B. Calpains promote neutrophil recruitment and bacterial clearance in an acute bacterial peritonitis model. Eur. J. Immunol. 2013, 44, 831-841. [CrossRef]

83. Nassar, D.; Letavernier, E.; Baud, L.; Aractingi, S.; Khosrotehrani, K. Calpain Activity Is Essential in Skin Wound Healing and Contributes to Scar Formation. PLoS ONE 2012, 7, e37084. [CrossRef]

84. Park, S.G.; Shin, H.; Shin, Y.K.; Lee, Y.; Choi, E.-C.; Park, B.-J.; Kim, S. The Novel Cytokine p43 Stimulates Dermal Fibroblast Proliferation and Wound Repair. Am. J. Pathol. 2005, 166, 387-398. [CrossRef]

85. Sun, Y.; Chen, X.; Xu, Y.; Liu, Q.; Jiang, X.; Wang, S.; Guo, W.; Zhou, Y. Thymosin $\beta 4$ is involved in the antimicrobial immune response of Golden pompano, Trachinotus ovatus. Fish Shellfish Immunol. 2017, 69, 90-98. [CrossRef] [PubMed]

86. Hwang, D.; Kang, M.; Jo, M.J.; Seo, Y.B.; Park, N.G.; Kim, G.-D. Anti-Inflammatory Activity of $\beta$-thymosin Peptide Derived from Pacific Oyster (Crassostrea gigas) on NO and PGE2 Production by Down-Regulating NF- $\mathrm{kB}$ in LPS-Induced RAW264.7 Macrophage Cells. Mar. Drugs 2019, 17, 129. [CrossRef] [PubMed]

87. Diotallevi, M.; Checconi, P.; Palamara, A.T.; Celestino, I.; Coppo, L.; Holmgren, A.; Abbas, K.; Peyrot, F.; Mengozzi, M.; Ghezzi, P. Glutathione Fine-Tunes the Innate Immune Response toward Antiviral Pathways in a Macrophage Cell Line Independently of Its Antioxidant Properties. Front. Immunol. 2017, 8, 1239. [CrossRef] [PubMed]

88. Fujii, N.; Minetti, C.A.; Nakhasi, H.L.; Chen, S.W.; Barbehenn, E.; Nunes, P.H.; Nguyen, N.Y. Isolation, cDNA cloning, and characterization of an 18-kDa hemagglutinin and amebocyte aggregation factor from Limulus polyphemus. J. Biol. Chem. 1992, 267, 22452-22459. [CrossRef]

89. Bruhn, K.W.; Spellberg, B. Transferrin-mediated iron sequestration as a novel therapy for bacterial and fungal infections. Curr. Opin. Microbiol. 2015, 27, 57-61. [CrossRef]

90. Liu, W.; Yan, M.; Liu, Y.; Wang, R.; Li, C.; Deng, C.; Singh, A.; Coleman, W.G., Jr.; Rodgers, G.P. Olfactomedin 4 down-regulates innate immunity against Helicobacter pylori infection. Proc. Natl. Acad. Sci. USA 2010, 107, 11056-11061. [CrossRef] 
91. Maizels, R.M.; McSorley, H.J. Regulation of the host immune system by helminth parasites. J. Allergy Clin. Immunol. 2016, 138, 666-675. [CrossRef]

92. Wynne, J.W.; O'Sullivan, M.G.; Cook, M.T.; Stone, G.; Nowak, B.F.; Lovell, D.R.; Elliott, N.G. Transcriptome Analyses of Amoebic Gill Disease-affected Atlantic Salmon (Salmo salar) Tissues Reveal Localized Host Gene Suppression. Mar. Biotechnol. 2008, 10, 388-403. [CrossRef] 